\title{
TEGAL SUCI : PURA HINDU TANPA TEMPAT PEMUJAAN (Sejarah dan Makna di Balik Pertautan Islam-Hindu di Kintamani Bali)
}

\author{
Desak Made Oka Purnawati \\ Universitas Pendidikan Ganesha \\ Desakmade1705@gmail.com
}

\begin{abstract}
Abstrak
Penelitian ini bertujuan untuk mengetahui sejarah Pura Tegal Suci, bentuk, struktur, proses upacara, keyakinan, nilai dan sikap masyarakat tentang Pura Tegal Suci yang menampakkan keunikan jika dibandingkan dengan pura-pura umumnya di Bali, khususnya simbol persatuan bagi masyarakat setempat, menemukan serta menggali aplikasi nilai-nilai Islami yang melekat di Pura Tegal Suci. Penelitian ini menggunakan pendekatan sejarah dan hasilnya menunjukkan bahwa sejarah berdirinya Pura Tegal Suci tidak bisa dilepaskan dari hubungan dagang sejak jaman Bali Kuno yang membawa para pedagang muslim Cina, Bugis dan Bajo. Mereka adalah golongan pedagang yang secara intens terlibat dalam jalur perdagangan dari Bali Utara menuju Bali Tengah. Daerah ini merupakan daerah persinggahan kaum pedagang yang menyebabkan penguasa di Bonyoh Kintamani memberikan satu lahan untuk dijadikan tempat sholat. Oleh umat Hindu lokal, tempat ini dipelihara tanpa menghilangkan makna-makna simbol persatuan lintas agama yang sudah dirintis dari sejak awal. Sekalipun belakangan muncul pro kontra diantara generasi muda tentang adanya usulan untuk merubah struktur pura mengikuti pola umum pura di Bali. Namun, setelah masyarakat diberikan pemahaman tentang sejarah kelahiran Pura Tegal masyarakat sepakat untuk mempertahan keaslian Pura ini sebagai bentuk kesederhanaan toleransi antarmasyarakat di pegunungan Bonyoh Kintamani dan menyikapi perbedaan yang tak akan lekang oleh waktu.
\end{abstract}

Kata Kunci : Pura Tegal Suci, Jaringan Perdagangan, Hindu dan Islam 


\begin{abstract}
This study aims to determine the history of Tegal Sari Temple, form, structure, rites's process, beliefs, values and attitudes about it's scriptures that reveal the uniqueness when compared with the other temple in Bali, especially a symbol of unity for the local community, discover and explore application of Islamic values inherent in Tegal Suci Temple. This study uses a historical approach and it results that the history of Tegal Suci Temple can not be separated from trade relations since ancient Bali that brought Cina's Muslim traders, Bugis and Bajo. They are a class of traders who are intensely involved in the trade routes from north Bali to Central Bali. This area is a transit area of the merchants that imapct to the ruling in Bonyoh Kintamani give a land to be a place for sholat. By the local Hindus, the place is maintained without losing the meanings of symbols interfaith unity that has been initiated from the beginning. Even recently emerged pro and contra among the young generation about the course to change the structure of the temple follows the general pattern of temples in Bali. However, after once people are given an understanding of the history of the birth of Pura Tegal community agreed to retain the authenticity of this temple as a form of simplicity Bonyoh tolerance between communities in the mountains of Kintamani and addressing the differences that will not timeless.
\end{abstract}

Keyword : Tegal Suci Temple, trading network, Hindu and Muslim 
Pendahuluan

Bali Menyimpan misteri
terkait dengan eksistensi dan
pengaruh Islam terhadap kehidupan
masyarakat Bali yang identik dengan
Hindu. Hindu dengan simbol-simbol
pura sebagai tempat bersemayamnya
Tuhan menunjukkan keunikan
tersendiri terkait dengan
ditemukannya beberapa fenomena
pemujaan Ratu Mekah dengan
ketentuan - ketentuan yang halal dan
haram sebagai sarana ritual di pura.

Fenomena pura di Bali terutama di Bali Utara yang memuja Ratu Mekkah sudah diteliti tetapi belum terpublikasi secara luas. Tulisan Atmadja (2010) dan beberapa mahasiswa jurusan pendidikan sejarah seperti oleh $\mathrm{Ni}$ wayan Kerti (2011, Putriasih (2009) dalam bentuk skripsi telah menunjukkan hal tersebut. Demikian pula dengan fenomena pura Tegal Suci di Desa Bonyoh (Satu Desa Kuno di Pegunungan Kintamani) kemungkinan menyimpan satu misteri keterkaitan antara pengaruh perdagangan oleh pedagangpedagang Muslim pra Majapahit dengan Bali pedalaman.
Berbeda dengan pura-pura umumnya di Bali maka ada hal yang dianggap aneh karena faktanya Pura Tegal Suci dipercaya berkaitan dengan penduduk pertama yang mendiami kawasan ini. Struktur pura Twegal Suci faktanya tanpa tempat pemujaan. Secara kasat mata Pura ini merupakan sebidang tanah datar yang diposisikan sebagai Pura dan termasuk dalam jajaran dari 13 pura yang ada di Desa Bonyoh Kintamani. Tanah pura memiliki makna yang mengikat masyarakat Bonyoh khususnya dalam hal adat. Prosesi upacaranya unik, dilaksanakan setahun sekali dengan sarana sesajen yang juga unik. Keunikan dan keanehan ini dikalangan orang-orang muda dan orang-orang tua memicu konflik social berkaitan dengan adanya upaya untuk memodifikasi keberadaan Tanah Tegal Suci agar dibangun pura layaknya pura-pura umumnya di Bali, sedangkan kalangan tua ingin tetap melestarikan keasliannya.

Berdasarkan hal diatas maka Pura sebagai simbul persatuan dengan nilai keagamaan dihadapkan 
pada kontradiksi yang menimbulkan konflik. Oleh karena itulah maka keunikan-keunikan yang dianggap aneh ini perlu dikaji dan ditelusuri secara ilmiah dengan menggunakan metode penelitian sejarah yang mencakup heuristic, kritik sumber baik lisan maupun tertulis, interpretasi dan historiografi. Dengan demikian permasalahan seperti : Bagaimana sejarah berdirinya pura Tegal Suci menurut Teks tertulis dan keyakinan masyarakat desa Bonyoh sebagai pengempon pura,Bagaimana keterkaitan Pura Tegal Suci dengan intensitas pengaruh Islam pra Majapahit di Bali sehingga pura ini bisa mempersatukan masyarakat adat, dapat terjawab secara tuntas.

\section{Hasil dan Pembahasan}

\section{Sejarah Pura Tegal Suci}

Berdasarkan hasil penggalian informasi secara tertulis dengan melihat monografi desa dan membaca beberapa teks tertulis yang ada di kantor desa Bonyoh, serta berdasarkan hasil wawancara secara purposive yang kemudian dikembangkan dengan teknik snowball dengan tokoh, pemangku, dan warga desa Bonyoh diperoleh data tentang sejarah pura Tegal Suci ya. Berdasarkan Prasasti Pendem (nama ini sesuai dengan nama pura tempat prasasti disimpan), yang diperkuat dengan penuturan sesepuh desa adat Bonyoh, kaki Daweg (almarhum), yang didukung oleh bendesa adat Desa Bonyoh I Wayan Gandra, Perbekel Desa Bonyoh I Nyoman Denya, serta warga desa lainnya yaitu: Nang Sadug, Nyoman Nyirma, Made Windra, Jro Bayan Mucuk, Jro Bayan Nyoman, Wayan Lasmawan, dan Jro Bayan Lingga, bahwa Pura Tegal Suci dulunya merupakan sebuah petirtan atau tempat pemandian Rsi yang ikut mengungsi setelah kerajaan Jayapangus hancur di kawasan Sukawana Kintamani (Raja ini menurut keyakinan masyarakat Kintamani dikenal telah mengembangkan satu system perdagangan dengan pedagang asing Cina, Bugis Melayu dan Bajo di kawasan Bali Tengah dan Utara dengan mengawini putri dari seorang Syahbandar Cina di Pegonjongan Ping -An yang bernama Kang Cing Wei). Di tempat itu terdapat 
pesraman serta tempat permandian yang terdiri dari 9 pancuran yang bertingkat, dengan tingkatan paling tinggi ada di sebelah timur sekarang berdekatan dengan Pura Puseh desa Bonyoh Kintamani.

$$
\text { Rsi yang mendirikan }
$$
pesraman di kawasan itu (sekarang termasuk di sekitar kawasan pura Tegal Suci) adalah salah satu rsi yang ikut mengungsi ke kawasan hutan (yang sekarang bernama desa Bonyoh) setelah runtuhnya kerajaan Panijoran di Penulisan Kintamani. Saat itu pengungsian diikuti oleh dari Jro Penyarikan Nyoman, Rsi, dengan beberapa rakyat kerajaan. Mereka lari ke arah selatan, setelah kerajaan Jayapangus hancur diporakporandakan oleh badai besar. Setelah sampai dihutan tersebut, mereka mulai kelelahan dan akhirnya memutuskan untuk menetap dikawasan hutan tersebut, dan mendirikan sebuah kawasan pertapaan (pemujaan) dengan dilengkapi oleh tempat pemandian yang akhirnya merubah kawasan hutan menjadi kawasan pesraman atau tempat belajar mendalami ajaran tuhan. Diantara pengikut sang rsi tersebut ada pula pedagang dari negeri Bugis, Bajo dan juga Cina melayu (kemungkinan China pedagang ini ada juga yang menganut Islam dan Buda (ditunjukkan oleh adanya Pemujaan kepada ratu Ayu Subandar yang bertebaran di sekitar wilayah pantai Bali utara dan juga pedagang muslim lintas etnis yang memuja Ratu Mekah),sebagaimana tersurat pada prasasti Sukawana), yang saat badai melanda dan meruntuhkan keraton kerajaan Panijoran, mereka sedang berdagang di wilayah kerajaan Panijoran.

Pura Tegal Suci sekarang berada di ujung utara Desa Bonyoh, dengan luas areal sekitar 12 are, arealnya berbentuk kotak. Di sebelah timurnya adalah jalan (baru dibuat tahun 2010), sebelah utara, barat, dan selatannya adalah perumahan penduduk desa adat (warga yang memperoleh tanah pekarangan karena merupakan krama negak dalam jajaran desa adat Bonyoh). Secara empiris, pura ini pada dasarnya adalah sebidang tanah lapang yang sangat rata dengan hiasan rumput, dengan tanpa ada 
tempat pemujaan. Bahkan tembok pura juga tidak ada, yang membatasi areal pura dengan kawasan pemukiman dan jalan hanya pohon dapdap (turus) yang ditanam secara berjejer, yang saat peneliti melakukan observasi daun pohon ini telah habis dicari atau dipangkas oleh penduduk untuk diberikan ternak sapinya.

$$
\text { Menurut masyarakat }
$$

setempat, keberadaan pesraman ini lama kelamaan mampu menjadi daya tarik tersendiri bagi desa terdekat yaitu desa Kelaan yang berada disebelah selatan kawasan pura, sehingga lama kelamaan kawasan itu semakin ramai, dan akhirnya menjadi sebuah kawasan yang disebut benyahan (pecahan), yang lama kelamaan menjadi Bonyoh, yaitu desa Bonyoh Kintamani saat ini. Pada abad ke 12 Masehi, setelah kerajaan Jayapangus runtuh, terjadilah gejor (gempa bumi yang dahsyat) sampai membelah beberapa kawasan, sehingga pesraman dan pemandian ini tertutup oleh reruntuhan tanah sekitarnya, sehingga menjadi rata dan tanpa bekas. Sebagai wujud hormat dan mengenang pertapaan dan rsi yang berstana disana, maka setiap tahun diadakan upacara (piodalan) di kawasan tersebut, yang hingga saat ini terus dilakukan dan dipertahankan oleh masyarakat desa Bonyoh.

Piodalan di pura Tegal Suci dilakukan setiap tahun (kecuali terjadi leteh desa/ada orang meninggal), yang didahului dengan upacara metlamping, kemudian muat emping, dan mecacahin sebagai puncak piodalan di pura Tegal Suci. Terdapat sesuatu yang unik terkait dengan sesajen yang dihaturkan oleh masyarakat desa saat mecacahin (puncak piodalan di pura Tegal Suci), yaitu dimana sate atau ulam bantennya tidak boleh menggunakan daging babi, dengan sesajen yang diwadahi dungki (anyaman bambu yang berbentuk keranjang) besar seperti layaknya para pengembara timur tengah yang biasanya diletakkan di punggung unta atau kudanya. Menurut para tokoh masyarakat desa Bonyoh, pola dan sistim ritual upacara piodalan (upacara setahun sekali) sebagaimana yang ada di pura Tegal 
Suci, sangat berbeda dengan purapura lainnya yang mereka sungsung (among dalam segala aktivitasnya). Mereka meyakini bahwa sistim dan peralatan upacara tersebut tidak terlepas dari pengaruh luar Hindu, yang diyakini dibawa oleh salah satu panjak (pengikut) rsi dan pedagang yang dulunya mengungsi ke daerah tersebut di jaman dahulu.

Upacara di pura Tegal Suci, dilakukan hanya dalam satu hari, dan tidak ada upacara pendahuluan, seperti layaknya upacara di purapura kahyangan desa yang ada di desa Bonyoh. Setelah metlamping dan muat emping (upacara yang bertalian dengan menjelang panen padi gogo) bagi masyarakat desa Bonyoh, maka akan dilakukan upacara piodalan di pura Tegal Suci, yang disebut dengan mecacahin (sesajen ditaruh sedemikian rupa, dan bertebaran di areal tanah pura tanpa pelinggih atau tempat upacara khusus). Kondisi ini menyerupai pola persembahyangan kaum muslim (agama islam), dimana posisi antara pemimpin upacara dan masyarakat lainnya sejajar, dengan tanpa ada tempat pemujaan sama sekali.
Namun mulai lima tahun terakhir, bakti desa (sesajen desa adat) yang berupa petirtan dan segala iringannya) dibuatkan lapan (tempat dari turus dapdap berbentuk segi empat, dengan ukuran sekitar $1.5 \mathrm{~m}$ x $3 \mathrm{~m}$. Sementara sesajen masyarakat dan jro kubayan dan saih peduluan (kelompok 16 desa adat) ada di bagian depan, kemudian diikuti oleh masyarakat lainnya di samping sesajen yang mereka persembahkan. Kegiatan upacara piodalan biasanya dilakukan mulai pukul 20.00 wita, yang didahului dengan isyarat suara kulkul (bunyi kentongan 21 kali, sebagai penanda bahwa upacara akan segera dimulai. Setelah bunyi kulkul (kentongan desa), maka masyarakat mulai berdatangan ke areal pura dengan sesajennya masing-masing. Kegiatan upacara biasanya berakhir sebelum tengah malam (pukul 24.00), dan setelah itu, sebelum masyarakat keluar dari areal pura (tanah Tegal Suci), maka masyarakat secara sendiri-sendiri akan ngajum kepada para leluhur, khususnya kepada Ide Begawan dan pengikutnya yang berstana di kawasan pura Tegal Suci, dengan 
menyisakan sedikit bahan-bahan sesajen di tanah dengan alas canang. Hal ini tidak jauh berbeda dengan apa yang dilakukan oleh umat muslim pada saat menjelang hari raya lebaran, dengan nyekar ke kuburan keluarganya masing-masing dengan membawa sejumlah peralatan tertentu. Menurut keyakinan masyarakat desa Bonyoh, lokasi pura, kontur pura, dan sistim serta peralatan sembahyang yang digunakan di pura tersebut serupa dengan apa yang dibawa umat muslim saat nyekar kubur.. Namun setelah ditanyakan apakah ada catatan tertulis, atau prasasti dan sejenisnya yang memuat tentang hal itu, mereka menyatakan sejak mereka ingat sebagai manusia dan ngayah sebagai desa adat, sudah demikian adanya, dan informasi yang mereka yakini sebagai sebuah kebenaran diperoleh dari pitutur anak lingsir (tuturan orang tua yang diwarisi dan diyakini secara turun temurun).

\subsection{Keterkaitan Antara Pura Tegal Suci dan Pengaruh Islam di Bali}

Merujuk pada data yang diperoleh secara langsung dengan tokoh masyarakat (Nang daweg), prajuru desa adat (Wayan Gandra), kepala desa dinas (Nyoman Denya), kalangan teruna teruni (Wayan Sadu dan Ni Nyoman Koti), diperoleh fakta bahwa, sampai saat ini tidak ada satu bukti tertulis apapupun yang mereka dapat tunjukkan terkait dengan keberadaan pura Tegal Suci, dan sistim upacara yang harus mereka lakukan setiap tahun. Mereka menyatakan bahwa, ada prasasti yang bertalian dengan sejarah desa Bonyoh termasuk sejarah Tegal Suci, namun sampai saat ini mereka tidak berani menggalinya, karena telah tersimpan secara rapi di pura Pendem (sebuah pura kahyangan desa yang diyakini sebagai penyimpanan). Hal ini sejalan dengan nama pura tersebut, yaitu pura Pendem yang maknanya tidak jauh berbeda dengan tanam atau sembunyikan dengan suatu tujuan tertentu.

Apa yang mereka ketahui dan yakini seperti saat ini, diperoleh 
secara turun temurun dan petuah para penglingsir desa yang telah almarhum. Nang Sadug, salah seorang penua (orang tertua di desa Bonyoh saat ini), menyatakan bahwa, memang benar menurut informasi yang didengar dari para tetuanya, bahwa di Pura Tegal Suci dulu ada juga pengikut muslim sang rsi saat mengungsi ketika kerajaan Jayapangus runtuh .Sebagai penghormatan terhadap toleransi keyakinan, maka upacara di pura Tegal Suci, bahannya tidak boleh ada yang mengandung daging babi. Namun versi lain dikemukakan oleh Jro Kubayan Lingga, yang menyatakan bahwa memang benar ada pengaruh Islam terkait dengan kontur tanah dan sistim ritual upacara di pura Tegal Suci, namun hal itu bukan disebabkan oleh pengikut maha rsi, melainkan karena saat itu, ada sekelompok orang dari desa Campuhan (yang sekarang bernama desa Taro pusat migran pertama dari kerajaan Kediri Jawa Timur, yang telah berdagang secara rutin dengan masyarakat desa Bonyoh, dan lama kelamaan mereka akhirnya menetap di kawasan tersebut, dan menjadi salah satu sisya (murid) kesayangan maha rsi. Karena peran sertanya yang dominan dalam pengelolaan aktivitas pesraman dan kasih sayang sang rsi, maka setelah meninggal, dibuatkanlah tempat pemujaan khusus, dimana sesajen yang boleh dihaturkan ditempat tersebut tidak boleh menggunakan daging babi, karena selama hidupnya, sang sisya ini tidak makan daging babi. Jadi tidak ada bukti tertulis yang mampu menjawab kebenaran dan historis dari tidak diperbolehkannya menggunakan daging babi di kawasan pura Tegal Suci saat pelaksanaan upacaranya.

Menurut sebagian besar responden, bahwa keberadaan pura Tegal Suci sangat penting artinya dalam mempertahankan dan mempersatukan perbedaan keyakinan yang berkembang di tengah-tengah masyarakat. Disisi lain, mereka juga memandang bahwa sejak dahulu, pura Tegal Suci telah berfungsi sebagai pemersatu perbedaan dan penumbuhan rasa toleransi dikalangan masyarakat, yang terbukti dari banyaknya masyarakat dari berbagai aliran yang 
belajar agama dan ilmu kesucian di tempat tersebut, dengan tanpa memandang kasta, agama, dan asal daerah. Hal ini dibenarkan oleh kelian desa adat Bonyoh, bahwa pura Tegal Suci merupakan salah satu simbolisme keberagaman dan unifikasi perbedaan di tengah-tengah masyarakat. Menurut A.A Gede Oka (salah seorang penglingsir puri Saraswati Bangli), yang secara historis keluarganya memiliki hubungan dekat dengan kawasan pura ini, bahwa pura Tegal Suci sangat penting artinya bagi kebertahanan dan pelestarian nilainilai desa adat dan budaya bagi masyarakat sekitarnya. Hal ini bisa dilihat dari bahan-bahan sesajennya, sistim upacaranya, bentuk puranya, dan keterbukaannya bagi perbedaanperbedaan yang ada di masyarakat, khususnya masyarakat desa adat Bonyoh.

\subsection{Pandangan, Sikap, dan Ketaatan Warga Desa Terhadap Pura Tegal Suci}

Berdasarkan informasi yang diperoleh dari hasil wawancara, khususnya dengan para tokoh masyarakat (Wayan Gandra, Nyoman Denya, Kadek Ariawan, Nyoman Nyirma,Made windra, Jro Kubayan Lingga, Nang Sadug,Wayan Sadu, Ni Nyoman Koti, dan Kadek Geson) diperoleh kesimpulan bahwa: pura Tegal Suci menurut mereka tidak ada bedanya dengan pura kahyangan desa yang mereka sungsung selama ini (kesamaan dari ketaatan dan rasa bakti mereka pada sesuhunan yang berstana di masing-masing pura). Sementara dilihat dari sikap mereka terhadap keberadaan dan makna simbolisme kesakralan pura Tegal Suci, mereka sangat hormat dan taat pada awig-awig atau dresta (walaupun tidak tertulis) terkait dengan pura Tegal Suci.

Bertalian dengan kesakralan pura Tegal Suci, fakta yang terungkap di lapangan (berdasarkan hasil wawancara dan pengakuan warga masyarakat), pura ini memiliki tingkat kesakralan (tenget) yang demikian rupa. Pernah kejadian, ada seorang warga yang mengikatkan tali sapinya di pagar pura (kayu dapdap), karena rumput disekitaran area pura sangat lebat, sehingga berharap 
sapinya bisa memakan rumpun tersebut. Namun selang beberapa saat, belum satu jam berlalu tiba-tiba sapinya beringas, terus berlarian dengan tali ikat yang putus kearah tegalan masyarakat, dan akhirnya tersangkut talinya disebilah kayu, dan sapi tersebut akhirnya mati karena kehabisan nafas akibat ingin lepas dari sangkutan kayu. Sementara si empunya, malamnya mulai sakit, panas yang tinggi dan lunglai. Sehingga atas petunjuk tetua adat dan setelah ditanyakan pada orang pintar (secara spiritual), yang bersangkutan harus menghaturkan guru piduka (permohonan maaf) dengan dilandasi serangkaian sesajen yang dipimpin oleh Jro Kubayan.

Kejadian tersebut bukannya hanya sekali, menurut penuturan warga desa, pernah ada seorang saudagar sapi yang kebetulan lewat di jalan sebelah timur pura, berhenti dan mengikatkan tali sapi yang baru dibelinya, karena harus kencing, maka tidak berselang lama, sapi tersebut juga beriengas dan berlarian masuk ke areal hutan desa, dan sampai sekarang tidak pernah ditemukan, serta sang saudagar sakit dengan gejala badan panas dan lunglai, dan akhirnya meninggal dunia. Kejadian-kejadian tersebut, semakin memperkuat tingkat ke kesakralan pura Tegal Suci di mata warga desa adat Bonyoh.

Berdasarkan hasil paruman desa adat tahun 1981, telah ditegaskan tentang tata kelola dan peswara mengenai pura-pura kahyangan desa termasuk pura Tegal Suci, dimana warga desa akan dikenai sanksi manakala melakukan aktivitas-aktivitas: pencurian, merusak, dan membiarkan terjadinya kerusakan di area pura, dengan tingkatan sanksi yang berjenjang secara kuantitatif dan kualitatif. Fakta ini membuktikan bahwa secara regulatif dan yuridis serta subjektif, pura Tegal Suci memiliki tingkat kesakralan yang sangat tinggi, dan sangat dipatuhi oleh semua warga desa. Terlebih dengan adanya peristiwa-peristiwa yang membuat kesakralan areal pura semakin tinggi. Disisi lain, berdasarkan hasil wawancara dengan tokoh masyarakat, setiap warga desa Bonyoh terlepas dari mereka adalah penduduk asli maupun pendatang 
wajib taat pada aturan tersebut, dan kondisi ini semakin diperkuat dengan adanya fakta dan informasi secara turun temurun terkait dengan sakralnya pura Tegal Suci.

\subsection{Faktor-Faktor Pembeda Pura} Tegal Suci Bonyoh

Bersandar pada hasil penelusuran secara observasional dan wawancara dengan responden, diperoleh fakta bahwa terdapat sejumlah kekhasan pura Tegal Suci manakala dibandingkan dengan purapura lainnya yang ada di wilayah desa adat Bonyoh.

(1) faktor kontur (triloka), tampak bahwa pura Tegal Suci tidak terdiri dari 3 bagian area seperti halnya pura-pura lainnya, yaitu utama mandala, madya mandala, dan nista mandala. Pura ini hanya terdiri dari satu petak tanah lapang yang datar dan tidak ada pembagian utama, madya, dan nista.

(2) faktor keberadaan pelinggih (tempat pemujaan), pura Tegal Suci tidak memiliki tempat pemujaan sama sekali seperti layaknya pura-pura lainnya di Bali.

(3) faktor struktur, pura Tegal Suci tidak memiliki struktur seperti halnya pura-pura pada umumnya yang ada di Bali. Pura ini hanya terdiri satu area, yaitu utama loka. Area ini merupakan tempat persembahyangan, sekaligus sebagai tempat ngajum (rasa bakti pada leluhur dan para dewa).

(4) faktor penataan lingkungan. Pura Tegal Suci secara geografis terletak di ujung utara desa adat Bonyoh, dan bersanding langsung dengan tempat pemukiman masyarakat, dan hanya dibatasi oleh pagar pembatas tanaman hidup. Hal ini tidak lazim bagi tempat suci lainnya yang ada di desa tersebut. Pura-pura lainnya yang ada di desa Bonyoh, lokasinya mengikuti arah pembagian tri loka, dengan lokasi yang tersendiri dan tidak berdekatan dengan rumah penduduk. Disamping itu, pura Tegal Suci hanya dibatasi dengan kayu 
dapdap sebagai penyengker (tembok pembatasnya).

(5) faktor kelengkapan upacara piodalan di pura Tegal Suci. Untuk pelaksanaan piodalan tahunan, kelengkapan upacara di pura Tegal Suci tidak sama dengan pura-pura lainnya yang termasuk dalam kahyangan desa di desa Bonyoh. Kelengkapan yang dibutuhkan dan bentuk sesajen (banten) yang dihaturkan oleh masyarakat sangat unik, karena keranjang (anyaman bambu) dengan komponen utama: keladi, ubi, timus, pisang biu kayu, daging ayam, sate ayam, dan kacang saur, sehingga kontur sesajennya benar-benar unik (seperti bekal bepergian jauh ).

\subsection{Keberadaan Pura Tegal Suci dan Aplikasi Ajaran Tri Hita Karana}

Wawancara yang dilakukan dengan salah satu responden kunci, yaitu Bendesa adat desa Bonyoh (I Wayan Gandra) dan didukung oleh pernyataan Perbekel desa dinas (i Nyoman Denya), menyatakan bahwa keberadaan pura Tegal Suci merupakan salah satu simbolisme dan contoh realistik bagi penerapan ajaran Tri Hita Karana, yaitu tiga pertalian keseimbangan dan keharmonisan antara manusia dengan manusia, manusia dengan Tuhan, dan manusia dengan lingkungannya. Hal tersebut dapat dilihat dari penegasan Nang Sadug (tokoh tetua desa) yang menyatakan bahwa kawasan pura Tegal Suci dan hubungannya dengan tata kelola lingkungan di sekitarnya mencerminkan penerapan konsep Tri Hita Karana, karena disanalah kita dapat melihat bagaimana keseimbangan antara hubungan manusia dengan manusia lainnya, tanpa memandang ras, suku, dan agama atas nama keharmonisan. Disamping itu, lingkungan alamiah yang menghiasi areal pura merupakan sebuah bukti, bagaimana tertatanya lingkungan secara alamiah dan rapi, walau disekitarnya terdapat rumah tinggal penduduk. Demikian juga, bagaimana masyarakat berbondong-bondong datang ke pura saat dilakukan piodalan, untuk menghaturkan sembah bakti dan rasa 
syukur pada sang maha kuasa. Pura Tegal Suci desa Bonyoh, merupakan salah satu cermin terpolanya regulasi dan aplikasi ajaran Tri Hita Karana, sehingga penting untuk dilakukan pewarisan sedemikian rupa pada generasi muda kedepan, khususnya bagi masyarakat desa adat Bonyoh sebagai pengempon atau penyungsung pura tersebut.

\section{KESIMPULAN}

Berdasarkan hal tersebut maka keberadaan Pura Tegal Suci dan aplikasi ajaran Tri Hita Karana adalah keberadaan pura Tegal Suci merupakan salah satu simbolisme dan contoh realistik bagi penerapan ajaran tri hita karana, yaitu tiga pertalian keseimbangan dan keharmonisan antara manusia dengan manusia, manusia dengan Tuhan, dan manusia dengan lingkungannya. Hal tersebut dapat dilihat dari penegasan nag sadug (tokoh tetua desa) yang menyatakan bahwa kawasan pura Tegal Suci dan hubungannya dengan tata kelola lingkungan di sekitarnya mencerminkan penerapan konsep tri hita karana, karena disanalah kita dapat melihat bagaimana keseimbangan antara hubungan manusia dengan manusia lainnya, tanpa memandang ras, suku, dan agama atas nama keharmonisan. Disamping itu, lingkungan alamiah yang menghiasi areal pura merupakan sebuah bukti, bagaimana tertatanya lingkungan secara alamiah dan rapi, walau disekitarnya terdapat rumah tinggal penduduk. Demikian juga, bagaimana masyarakat berbondong-bondong datang ke pura saat dilakukan piodalan, untuk menghaturkan sembah bakti dan rasa syukur pada sang maha kuasa. Pura Tegal Suci desa Bonyoh, merupakan salah satu cermin terpolanya regulasi dan aplikasi ajaran tri hita karana, sehingga penting untuk dilakukan pewarisan sedemikian rupa pada generasi muda kedepan, khususnya bagi masyarakat desa adat Bonyoh sebagai pengempon atau penyungsung pura tersebut.

\section{Daftar Pustaka}

Artana, M. B. (2003). Landasan Kebudayaan Bali, Yayasan Dharma Sastra, Denpasar 
Agung, I. A. A. G. 1989. Bali pada Abad XIX, Gadjah Mada University Press, Yogyakarta.

Awig-awig Desa Bonyoh (tt).

Atmaja, N.B. (1998). "Sistem Pertanian Pada Masyarakat Bali Kuno". Aneka Widya, VIII, Nomor 17. (2002). Tanah Paruman Desa di Desa Adat Julah, Buleleng, Bali: Pengelolaan, Alih Status, dan Implikasinya terhadap Desa Adat. Laporan Penelitian.

Jakarta: Pasca Sarjana UI.

Babi Pemacek: Masukan

Finansial bagi Desa Adat

Julah, Buleleng, Bali.

Laporan Penelitian: IKIP

Negeri Singaraja.

Arga. (2000). Peraturan Irigasi

dalam Awig-awig Subak

Buleleng. Denpasar:

UNUD Bali.

Anonim, (1990). Desa-Desa Kuno di

Bali. Denpasar: Balai Pustaka.
Bagus, G. N., 1971. Kebudayaan Bali. Dalam Koentjaraningrat (ed), Manusia dan Kebudayaan di Indonesia, Jambatan, Jakarta. Halaman 284-305. Berger P. L, 1997. Religion And Globalization, Soge Publications, London-New Delhi.

Carspecken, P.F., (1998). Critical Etnography in Educational Research: A Theoritical an Practical Guide. London and New York: Routledge. Eiseman, F.B. 1989. Bali Sekala and Niskala, Volume I: Essy on Relegion, Ritual, and Art, Periplus Edition, Berkeley and Singapore:

Geertz, H. dan Geertz, C. 1975.

Khinsip in Bali, The

University of Chicago

Press, Chicago.

Geertz, C., 1973. The Interpretation of Culture: Selected Essay, Basic Bokks Inc, New York.

Griadi, W. (1999). Otonomi Desa Adt dan Kedudukannya dalam Tata Hukum 
Indonesia. (Makalah).

Denpasar: MPLA Bali.

Kaler, I. G. K. (2001). Butir-butir Tercecer tentang Adat Bali Jilid I. Denpasar: Bali Agung.

Kertih. (2005). Konsep Ajeg Bali

(Hindu) Berbasis Ideologi

Tri Hita Karana Dimaknai

Di Lingkungan Sekolah. (Penelitian). Singaraja: IKIP Negeri Singaraja.

Kardji, I. W. (2003). "Kiwa Tengen dalam Budaya Bali”. Dalam Jiwa Atmaja (ed.).Kiwa-Tengen dalam Budaya Bali. Denpasar: Kayu Mas. Halaman 1332.

Lasmawan, W. (2001). Tanah Laba Pura dan Pergeseran Nilai Sosial-Ekonomi

masyarakat Pedesaan. Jepang. The Toyota Foundation-Grant Number 017-Y-2000. (1991). Peranan saih nembelas dalam pembangunan fisik di Desa Bonyoh Kecamatan Kintamani Kabupaten
Bangli (Skripsi). FKIP

$$
\text { UNUD - Bali }
$$

Milles and Huberman. (1994).

Analisis Data Kualitatif.

Jakarta: Graffiti Prress.

Mantra I.B, 1996. Landasan

Kebudayaan Bali,

Yayasan Dharma Sastra,

Denpasar

Monografi Desa Bonyoh Kecamatan

Kintamani Kabupaten

Bangli - Bali.

Parisadha Agama Hindu Bali, (1978). Upadesa tentang Ajaran-ajaran Agama Hindu. Denpasar:

Parisadha Hindu Dharma.

Pitana, I Gde. (2001). Dinamika Masyarakat dan Kebudayaan Bali. Denpasar: PT. BP. Rtaning Jagad Bali, tt, Denpasar.

Sujana, N. Naya. (2000). Manusia Bali di Persimpangan Jalan. Denpasar: PT. BP. Rtaning Jagad Bali, tt, Denpasar.

Tisna, (2000). Etos Kerja Masyarakat Bali

Tradisional. Denpasar:

UNUD Bali. 
Wiana, (2002). Memelihara Tradisi

Veda. Denpasar: PT. BP.

Wiana, (2000). Makna agama Dalam

Kehidupan. Denpasar: PT.

BP. 